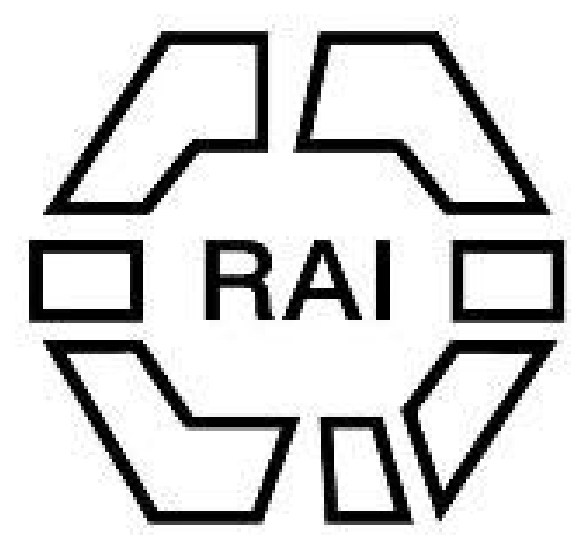

\title{
WILEY
}

\section{Some Notes on Orientation.}

Author(s): A. L. Lewis

Source: Man, Vol. 3 (1903), pp. 88-91

Published by: Royal Anthropological Institute of Great Britain and Ireland

Stable URL: http://www.jstor.org/stable/2839241

Accessed: 20-04-2016 18:50 UTC

Your use of the JSTOR archive indicates your acceptance of the Terms \& Conditions of Use, available at

http://about.jstor.org/terms

JSTOR is a not-for-profit service that helps scholars, researchers, and students discover, use, and build upon a wide range of content in a trusted digital archive. We use information technology and tools to increase productivity and facilitate new forms of scholarship. For more information about JSTOR, please contact support@jstor.org.

Royal Anthropological Institute of Great Britain and Ireland, Wiley are collaborating with JSTOR to digitize, preserve and extend access to Man 
" de l'Ile de Gerba (L'Anthropologie, VIII. (1897), p. 577) which treat of Gerbian " ceramic." Fig. 4, from a photograph enclosed by Dr. Bertholon in his communication, represents a potter's shop stocked with the common types of the wheel-made pottery of Gerba and Tunis.

I append an abstract of Dr. Bertholon's observations as stated in the work to which he refers. The ceramic industry of Gerba [Jerba] is confined to the villages of Kallala and Sédouikèche [Sedwikesh] in the southern part of the island. It is carried on by the men in large numbers. They use the clay of the place of manufacture and a primitive footdriven wheel, and model the vessels with their fingers and a small scraper; whereas everywhere else in North Africa, except at Bejà, Nabeul, and Sousse [Sûs] the pottery is made by the women, and by hand.

The forms of the vessels, as appear from the examples given on p. 55 of Dr. Bertholon's paper, follow eithør the pointed and long-necked amphoræ and other common.types of Græco-Roman pottery, or else the swollen trumpet-necked Oriental forms which were introduced at or after the Arab conquest. They thus fall exactly into line with the "Græco-Roman" and "Arab" styles of Tripolitan pottery immediately to the eastward of Gerba, which are described and figured in $\mathrm{M}_{\mathrm{AN}}$, 1901. 83. Characteristic of Gerba are the large pointed amphora called goula, which are in wide demand, the perforated kouskous-platters, and a sort of clay drum called darbouka, which is shaped like the common Arab water-bottle (gargoulette), but has its base replaced by a stretched skin.

The ornament is incised in the wet clay and is very simple, as will be seen from Fig. 5, repeated from Fig. 13 of Dr. Bertholon's paper.

The kilns are mainly composed of large jars held together by a mortar of lime and clay, which form a sort of air chamber between the inside and the outside of the kiln, and serve to retain the heat; only round the door is there a small area of ordinary masonry. The roof of the kiln is a low dome of clay, which itself resembles a segment of a great jar. These kilns will hold about 150 large jars; but the firing is uneven, and a good many jars are spoiled in each batch.

At the time of Dr. Bertholon's paper there existed 129 potteries in Gerba, almost all in
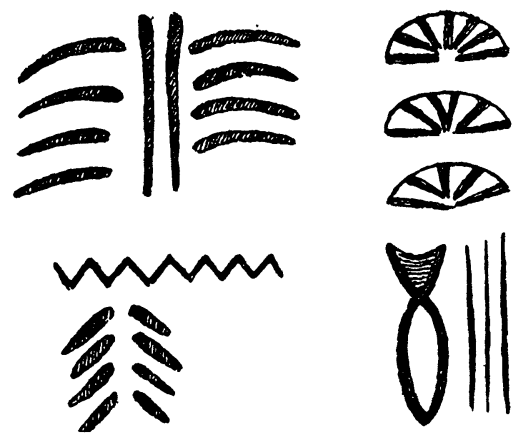

FIG. 5.-ORNAMENTS OF THE POTTERY OF GERBA. the two villages already mentioned; but some years previously the number was 144 , and there is apparently some reason to fear that this interesting fabric may be already in its last decline. JOHN L. MYRES.

\section{Archæology.}

Lewis.

Some Notes on Orientation. By A.L. Lewis, F.C.A., Treasurer of the Anthropological Institute.

A few months ago Dr. Rivers brought before another Society some cases in which certain people spoke of their right or left sides as being their north, south, east, or west sides, and he invited. any information or suggestions tending to explain the conclusion deduced by him that in Welsh and other languages there must have "gradually come " about a fixed association between south and right." It is only the fact of the question having been raised in this manner that emboldens me to publish these rather fragmentary memoranda which I have collected from time to time ; but, in order that their bearing on the subject may be at once understood, I may say that I think the reason of the 
association between south and right in Welsh and other languages is that the people who spoke those languages, when that association arose, were accustomed, for some ceremonial purpose or other, to turn to the east on certain occasions, when their right sides would, of course, become their south sides.

In the present day, indeed, nearly all Anglican church-goers do so turn to the east when the creeds are said or sung, and it may be that the origin of the association mentioned by Dr. Rivers goes no further back than does the origin of this present day custom; yet it may well go further, though by what exact channel we know not.

The Greeks looked on omens that appeared to the right as prosperous; but the Romans, on the contrary, regarded those that appeared to the left as being fortunate. Why was this? It was because, while both considered the north-east to be the favourable quarter, the Greeks in their augural ceremonies turned to the north, so that the northeast was on their right hand, but the Romans turned to the east, so that the north-east was on their left hand. Adams, in his Roman Antiquities, says that, according to Livy and Dionysius, the Roman augur turned to the east, but that Varro makes him look to the south. The southern facing would, however, seem to have been derived from the Etrurians, for Pliny remarks that thunder on the left is lucky because the east is on the left side of the heavens ; and that the Etrurians divided the heavens into sixteen parts, the first great division of four being from north to east, the second from east to south, the third from south to west, and the fourth and most unpropitious from west to north ; the eight parts on the east being called the left, and the eight parts on the west being called the right side of the heavens ; which could only be the case to those who were facing south. Whether, however, the Romans faced the east and the rising sun, or the south and the mid-day sun, the left and east or north-east side was for them the lucky one.

Other peoples have, however, taken different views as to the quarter of the heavens from which good things might be expected to come, and this has affected their opinion as to the lucky character of right or left.

Colonel Conder, speaking of an Altaic hieroglyph-a right hand-says : "I think " its meaning is possibly 'right,' that is auspicious or southern, as contrasted with left " - evil or northern - an idea well known in Semitic languages, and connected with the " words front for east and back for west. The origin of the idea (proper to the northern " hemisphere only) is that the mid-day is the south, the north is the region of night by " which the sun returns east. It is a general idea among Asiatics that the north is the " region of night and of demons, perhaps showing a race which came from the land of " darkness, where the nights in winter were very long. This is the simple and evident " reason "why a worshipper facing the rising sun regarded the right hand as propitious." That is Colonel Conder's explanation, and Landis also says that the Coreans consider that the north is the region of darkness and the abode of the shades, and that the Coreans on funeral occasions make a diagram of the "great bear"-seven stars on a board covered with black silk. A certain sect in Chaldea is also said to regard the pole-star as the abode of the spirits of its deceased members.

But Asia is a large place, with plenty of room in it for a variety of opinions, and Mr. E. H. Man has told us that the Andamanese consider the north-east to be the quarter in which the connection between heaven and earth exists, and call the north-east wind the "god-wind." He thought this was because Burmah, which was the nearest land, was in that direction. At some Hindu marriages the bride and bridegroom walk hand in hand round a sacred fire and then take seven steps towards the north-east. Major Gerini also says that in Siam the royal chair is always disposed. so as to face the north. This custom, he says, had its origin in the fact that the north is regarded among the nations of India and Indo-China as the most auspicious point of the compass, and that towards which the ground rises, culminating in the Meru mountain; next to the north in order of 
auspiciousness comes the east; the preference is, however, among Hindus given to the east, which, says Major Gerini, is considered to be the quarter of the gods, while the north is regarded as the quarter of man. Professor Sayce has told us that " in early "Sumerian days the heaven was believed to rest on the peak of the mountain of the " world in the far north-east, where the gods had their habitations." The Akkadians (according to Mr. R. Brown, F.S.A.), also called the north-east " the cardinal point of mountains," while the Assyrians called it "the rising," meaning, I presume, the point of sunrise. In the Journal of the Anthropological Institute (Vol. XXXI., p. 107), Mr. W. G. Sumner and M. Sieroshevski record that the Yakuts of North east Siberia, for purposes of divination, "draw two concentric rings on the table, and mark the north, north-east, " east, south-east, south, south-west, and west points on the exterior circle. The northern " point is called the chief road; the north eastern point, being the point of the summer " solstice, is the road for getting horned cattle; the east is the road of good luck; the " south-east, the winter solstice, is the road for obtaining horses; the south is the chief " road; the south.west is the road into the woods, and means death; the west is the " dark road of the devils."

Taking these various instances together it would seem that in all cases the quarters from which sunlight and divine influences generally come have been regarded as the fortunate quarters, and that the right or left sides have been considered lucky or otherwise and have been identified with this or that point of the heavens by reason of the position taken up by the different peoples in performing their respective rites and ceremonies.

It would be only natural to suppose that, if we could disentangle the various lines of thought about these matters, we might find out where this or that custom and the people by whom it was practised came from. If, for instance, we find in one stone circle apparent suggestions of sun-worship or observance, and in another circle apparent suggestions of northern-star-worship or observance, we might be tempted to ascribe the one to an influence coming from Chaldea and the other to an influence coming from Corea, or some other part of Asia. But the matter becomes more complicated when we find suggestions of both sun and star worship in the same circle or group of circles; then the explanation given by Sir Norman Lockyer of similar arrangements in Egyptian temples comes to our aid ; that is, that the priests who officiated in the temple watched the circumpolar stars in order to know when to prepare to welcome the rising sun. Yet there seems to have been a cult of northern-star-worship in some places which need not have conflicted with sun-worship, but may have been carried on side by side with it, and by the same people. Such a conjunction was noticed by Mr. Swann at the great Zimbabwe, and it may also be traced in the arrangement of the stone circles on Bodmin Moor and at Stanton Drew.

Lastly, and with some bearing on the question of right and left, there is a sort of symbolism of three and one-a kind of trinity and unity-which I have observed in connection with some of our stone circles. I first noticed it at a small circle in the Isle of Man, where there is an entrance formed by two earthern banks winding round outside the north-eastern quadrant of it; at the end of the bank on the left on entering was one large stone; at the end of the bank on the right were three large stones. Some years afterwards I found that the Great Orme and two other hills made a trinity to the northeast of the circle on Penmaenmawr ; and at Mitchellsfold circle in Shropshire I found a single high hill to the north-east, beyond which at an equal distance in the same line was another circle, and beyond that, still in the same direction, a group of three low hills. The well-known circle near Keswick has an apparently triple summit to the north-east and a single one of equal height to the north-west. At Swinside, also in Cumberland, there is a circle with a high hill to the south-west and three low ones to the north-east. At the Stannon circle, on Bodmin Moor, Rough Tor, in a north-easterly direction, is the 
most notable hill in sight, but, looking due east, three tips of Brown Willy, the highest hill in Cornwall, are visible over a low intervening ridge.

In the Scottish islands the circles at Callernish and at Brogar both have three hills to the north-east. In all these cases the three hills are connected with the east or northeast, and the one hill, except at Stannon, with the north-west or south-west, so that anyone facing north would have the three on his right and the one on his left, as in the case of the stones at the entrance to the avenue of the circle in the Isle of Man. At Stannon also the three points are on the right and the one peak on the left of anyone looking at them. I have no immediate explanation to offer of this circumstance, but should be glad to hear any suggestions about it.

A. L. LEWIS.

\section{REVIEWS.}

\section{Craniology.}

Turner.

A Contribution to the Craniology of the People of Scotland. Part I. 49
natomical. By Sir William Turner, K.C.B., D.C.L., F.R.S. Trans. Roy. Soc., 49 Edin., Vol. XL., Part III. Edinburgh : R. Grant, 1903. $31 \times 22$ cm. Pp. 547-613. With five plates. Price $7 s$.

It was with a feeling of surprise that the reviewer learned from the opening pages of this memoir that practically nothing is known of the anatomy of the people that inhabit the ancient kingdom of Scotland. Of all the kingdoms of the world one would expect that of the Scots to be, anatomically speaking, the best known, for no other, in proportion to its population, has produced so many professional students of the human body. The "blacksmith's mare is the worst shod," they say, and it is probably on oorresponding grounds that the Scots have been so neglected. This excellent and valuable memoir is the first systematic investigation of the shape, size, and formation of Scotch crania. Altogether the memoir deals with 176 skulls-117 of males and 59 of females-a collection which, after many years of persistent asking and patient waiting, Sir William Turner has brought together in the Anatomical Museum of Edinburgh University. For the greater part, the skulls were unearthed in the graveyards of Fife, of the Lothians, and Renfrew, but representative specimens have been obtained from many other Scotch counties, although hardly in sufficient numbers to afford safe ground for inference.

By reason of the many and extensive contributions which he has made, Sir William Turner stands easily first among British craniologists. It is clear from this monograph that his faith in the utility of the craniometrical methods, initiated by Retzius, and developed by Broca, Flower, and himself, is not a whit abated. Because of his belief, his long experience, and great ability, he is the man above all others in this country from whom a younger race of workers would welcome a pronouncement as to the exact goal on which craniologists are now moving. The craniometrical methods which he so clearly expounds have given rise to an alarming tide of literature. A younger generation of workers, which in their day will be passing custodians of this great heirloom, look at it askance because they cannot see how the elaborate and cumbersome methods at present in use are to help them in tracing the histories of the various races, or to give any rational account of how the numerous and diverse types of humanity came to be scattered as they are over the face of the earth.

Sir William Turner, so unlike many authors who publish contributions to craniology, has a definite aim in view. His aim is, as one may infer from the subject to be dealt with in Part II. of this memoir, to see what relationship there is between the skulls of the present day Scots and those of the prehistoric British races, and to those of the inhabitants of Western Europe. In short, his aim is to write a craniological history of the inhabitants of Scotland. 